\title{
Intimate Partner Violence: Controlling Behavior and Triggers of Aggression
}

\author{
Fernanda Monteiro de Castro Bhona ${ }^{1}$ \\ Carla Ferreira de Paula Gebara ${ }^{2}$ iD \\ Ana Regina Noto ${ }^{3}$ \\ Lélio Moura Lourenço ${ }^{4}$ (iD
}

\begin{abstract}
It is necessary to better understand the context in which intimate partner violence occurs. This study aimed to examine the occurrence of physical violence between intimate partners, based on the reports of women involved in these situations, by identifying the circumstances in which the physical violence occurs and the presence of controlling behavior in these relationships. We conducted a community survey using probabilistic sampling (144 women), administering the following instruments: socio-demographic questionnaire, CTS2, AUDIT. Fifty-seven women of our sample reported episodes of physical violence and were invited to participate in a semi-structured qualitative interview. Most of the reports obtained in the interviews did not confirm the episodes of physical violence initially identified by the scale, showing disagreements between the research instruments. Personal characteristics of the perpetrator of the violence, male alcohol use and aspects of the affective relationship were identified as important triggers of intimate partner violence. Controlling behaviors in combination with physical violence revealed varying degrees of domination occurring in the dyads.
\end{abstract}

Keywords: family violence, marital conflict, women, violence against women, psychological violence

\section{Violência entre Parceiros Íntimos: Controle de Comportamentos e Disparadores da Agressão}

\begin{abstract}
Resumo: Compreender o contexto em que ocorre a violência entre casais é necessário. Este estudo teve por objetivo estudar a ocorrência de violência física entre parceiros íntimos, a partir dos relatos de mulheres envolvidas nessas situações, identificando as circunstâncias nas quais o comportamento de violência física ocorre e a presença do controle de comportamentos nessas relações. Em levantamento comunitário por amostragem probabilística (144 mulheres), foram aplicados os seguintes instrumentos: questionário sociodemográfico, CTS2, AUDIT. Desta amostra, 57 mulheres referiram violência física e foram convidadas a responder entrevista qualitativa semiestruturada. A maioria dos relatos obtidos em entrevista não confirmou a violência física inicialmente identificada pela escala, evidenciando discordâncias entre os instrumentos de pesquisa. Características pessoais do autor da violência, o consumo de álcool masculino e aspectos do relacionamento afetivo foram identificados como importantes disparadores das agressões entre parceiros. O controle de comportamentos associado à violência física retratou diferentes graus de dominação nas díades.
\end{abstract}

Palavras-chave: violência na família, conflito conjugal, mulheres, violência contra mulher, violência psicológica

\section{Violencia entre Parejas: Control de Comportamientos y Desencadenantes de la Agresión}

\begin{abstract}
Resumen: Es necesario comprender el contexto en el que ocurre la violencia entre parejas. Este estudio tuvo como objetivo identificar la ocurrencia de violencia física entre parejas, basándose en los informes de mujeres involucradas en estas situaciones, los cuales presentan las circunstancias en las que ocurre el comportamiento de violencia física y la presencia de control comportamental en estas relaciones. En una encuesta comunitaria por muestreo probabilístico (144 mujeres), se aplicaron los siguientes instrumentos: cuestionario sociodemográfico, CTS2 y AUDIT. De esta muestra, 57 mujeres habían referido sufrir violencia física y fueron invitadas a responder una entrevista cualitativa semiestructurada. La mayoría de los informes obtenidos en la entrevista no confirmaron la violencia física inicialmente identificada por la escala, lo que apunta desacuerdos entre los instrumentos de la investigación. Las características personales del autor de la violencia, el consumo de alcohol por los hombres y los aspectos de la relación afectiva se identificaron como importantes desencadenantes de las agresiones entre parejas. El control del comportamiento asociado con la violencia física retrata diferentes grados de dominación en las díadas.
\end{abstract}

Palabras clave: violencia familiar, conflicto matrimonial, mujeres, violencia contra la mujer, violencia psicológica

${ }^{I}$ Tribunal de Justiça de Minas Gerais, Juiz de Fora-MG, Brazil

${ }^{2}$ Universidade Católica de Petropólis, Petropólis-RJ, Brazil

${ }^{3}$ Universidade Federal de São Paulo, São Paulo-SP, Brazil

${ }^{4}$ Universidade Federal de Juiz de Fora, Juiz de Fora-MG, Brazil

Article derived from the $\mathrm{PhD}$ thesis of the first author, supervised by the third and fourth author, defended in 2016, in the Post Graduate Program in Psychology at the Federal University of Juiz de Fora-MG.

Correspondence address: Fernanda Monteiro de Castro Bhona. Tribunal de Justiça de Minas Gerais, Av. Rio Branco, 2189, $12^{\circ}$ andar, Centro, Juiz de Fora-MG, Brazil. CEP 36.025-000. E-mail: fbhona@gmail.com
Violence between intimate partners is prevalent in several cultures and a serious public health problem. Research has been conducted on aggressions by men and women (Barros \& Schraiber, 2017; Razera, Mosmann, \& Falcke, 2016), but the impact of physical violence is more severe on women (Straus \& Gozjolko, 2014).

Violent acts can be physical, psychological, sexual, or involve deprivation or neglect (Dahlberg \& Krug, 2006). 
However, recent research on intimate partner violence have been showing the importance of identifying coercive control behavior among couples, in addition to other violent behaviors more easily recognized as such (Hamberger, Larsen, \& Lehrner, 2017; Johnson, Leone, \& Xu, 2014; Straus \& Gozjolko, 2014). Johnson (2011), for example, explains that violence between partners is not a homogeneous phenomenon and that what characterizes the various types of violence is the presence of coercive control or controlling behaviors between partners. Thus, Johnson's basic idea is that it is necessary to identify the patterns of control of each couple, and not the nature of the violent acts themselves. According to Johnson (2011), coercive control is characterized by an intention to gain general control over the partner, with a variety of control tactics, such as: economic abuse, emotional abuse, the use of children, threats and intimidation, constant monitoring, blaming the victim, invocation of male privilege and threats to involve the partner's work or family.

Johnson (2011) points out that the most severe situations of violence between couples involve a relational pattern in which physical and/or sexual violence is usually combined with an attempt to gain general control over the partner, situations that he calls "intimate terrorism." Intimate terrorism can be equally perpetrated by men and women, but men are the primary perpetrators in heterosexual couples. Victims of these situations can also respond with violence in an act of desperation, characterizing the so-called "violent resistance." There are also violent acts that may occur in response to everyday tensions, where discussions can lead to physical aggression, but without involving an attempt to gain general control over the partner, called by Johnson "situational couple violence," which is the most prevalent, being perpetrated in the same proportion by men and women. Thus, the occurrence of aggressive acts in a relationship does not necessarily imply the occurrence of abuse, which involves power, control, intention and intimidation, according to Straus and Gozjolko (2014).

Despite the relevance of the notion of coercive control for the study of violence between partners, data on these behaviors by men and women are scarce, there is no single measure nor consensual definition of the concept (Hamberger et al., 2017; Johnson et al., 2014; Straus \& Gozjolko, 2014). From now on we will use the expression controlling behavior, as adopted in a study by the World Health Organization, in order to apply the concept in our study (Garcia-Moreno, Jansen, Ellsberg, Heise, \& Watts, 2006).

In a study conducted in the United States, Bair-Merritt, Mandal, Epstein, Werlinich and Kerrigan (2015) described the triggers of aggressions, that is, the circumstances that immediately preceded the violent behavior between couples in a clinical sample. Respondents mentioned conflicts about domestic and parental responsibilities; use of alcohol and other drugs; discussions aimed at being heard by the partner; previous experiences of violence. The literature review carried out by Flynn and Graham (2010) pointed out, in addition to these circumstances, the personal attributes of the perpetrator; conflicts over financial issues; provocations/ threats; and attempts to control the partner.

Considering this scenario, more studies addressing the relational context of the conflicts that lead to violence between partners in different cultures are needed, specifically in low- and middle-income countries (Capaldi, Knoble, Shortt, $\& \mathrm{Kim}, 2012$ ). There is also a need for more information in addition to prevalence data; adding qualitative information to quantitative data is fundamental (Woodin, Sotskova, \& O'Leary, 2013).

In our research, we aimed to examine the occurrence of physical violence between intimate partners, based on reports of women involved in these situations, by identifying the circumstances in which the physical violence occurs and the presence of controlling behaviors in these relationships.

\section{Method}

\section{Participants}

We used a combination of quantitative and qualitative methods in our study, in a follow-up of a previous research's sample (Gebara et al., 2015). Initially, a survey was conductedin 2011/2012 - with a representative household sample from two neighborhoods with different socioeconomic profiles in a medium-sized city in the state of Minas Gerais (Gebara et al., 2015). This investigation addressed patterns of domestic violence and alcohol use among women and involved 905 participants. Among them, 144 women were identified who lived with a partner and who were involved in episodes of physical violence.

In 2015/2016, a second data collection survey was carried out with those 144 women who reported physical violence in the initial survey. In this second survey, the women answered the instruments used in the previous survey and also participated in a semi-structured interview. The semi-structured interview aimed to investigate the context of the situations of physical violence between intimate partners.

The inclusion criteria for the initial study were being a woman aged 18-60 years; literate; and without obvious cognitive impairments. To achieve the goals of the second survey, these women should also have experienced physical violence in the relationship with their partner (either as victims and/or as perpetrators), as measured by applying the physical violence scale employed in the first study.

The 144 women identified in the initial study were divided into three groups, according to the role played in the violence episodes: victims of their partners (27), perpetrators of aggression against partners (32), involved in mutual violence with the partner (85). We intentionally selected the participants for this study's final sample. For all three groups victims, perpetrators and those involved in mutual violence we sought to select women from both neighborhoods, taking into account the level of alcohol use of the women and her 
partners, so that these characteristics were proportionally represented in each group. These variables were identified in the initial household survey and, according to the literature, are relevant in understanding intimate partner violence (Capaldi et al., 2012).

In addition, we sought to select for each group women who participated in more episodes of physical violence, in order to better characterize the phenomenon. Among the 144 women identified in the first survey, 31 had changed residence at the time of the second survey, seven were not found at their homes, six refused to participate again in the research, and two had died. Of the remaining 98, 57 were intentionally selected, according to the criteria mentioned above. Thus, the final sample for this study comprised 57 women: 15 in the "victims" group, 14 in the "perpetrators of aggression" group and 28 in the "mutual violence" group. About $70 \%$ of these women resided in the lower income neighborhood.

\section{Instruments}

The instruments employed in the first and second data collection were:

Socio-Demographic Questionnaire. Covers information about age, race, religion, education level of the woman and partner, occupation of the woman and alcohol use of the partner. It was applied in the form of an interview, with multiple-choice questions.

Alcohol Use Disorders Identification Test (AUDIT). AUDIT is a screening tool for assessing patterns of alcohol use. Composed of 10 multiple-choice questions, it measures consumption amount and frequency, dependence symptoms and harmful consequences of consumption (Babor, HigginsBiddle, Saunders, \& Monteiro, 2006). AUDIT provides a score for the risk level associated with the pattern of alcohol use. It was already validated in Brazil and in other several countries, with good levels of sensitivity (average of 0.90 ) and specificity (average of 0.80) for detecting harmful alcohol use (Babor et al., 2006; Lima et al., 2005).

Revised Conflict Tactics Scales (CTS2). These scales measure violence between partners by assessing data on the respondent and her partner. The instrument consists of 78 items investigating whether the respondent or the partner adopted certain behaviors, distributed into subscales addressing the occurrence of negotiation, psychological aggression, physical violence, consequences of violence on health (injuries) and sexual coercion within the relationship. The scales were evaluated in Brazilian samples for conceptual equivalence, semantics and psychometric properties, showing an internal consistency between $0.65-0.86$, with intra-observer reliability (kappa) above 0.75 (Moraes, Hasselmann, \& Reichenheim, 2002; Reichenheim, Klein, \& Moraes, 2007). For this study, we only used data from the scales assessing physical violence and the consequences of violence on health (injuries).

The second data collection procedure included a semistructured interview script. This instrument addressed respondents' personal definition of intimate partner violence; information about the context of episodes of violence perpetrated by both partners, including those occurred in previous relationships; each person's reactions to the violence; and alcohol use related to these episodes. Controlling behavior was investigated by adapting three questions used in the World Health Organization's multi-country study (Garcia-Moreno et al., 2006), namely, "Does your partner control your behavior? For example: does he restrict your contact with your family, prevent you from seeing friends, or insist on knowing where you are at all times? Do you control his behavior like that?" Controlling behavior was only considered as present when the interviewee indicated that she or her partner abstained from doing something as a result of this control, that is, when control was actually exercised within the relationship, according to what was reported.

\section{Procedure}

Data collection. For both surveys, undergraduate psychology students approached the participants at their homes. After the women have agreed to participate in the studies and signed the Free and Informed Consent Form (ICF), the students administered the socio-demographic and AUDIT questionnaires, both in the form of an interview. The participants then responded to CTS2 (self-completion). After completing these instruments, the second survey included inviting the women to participate in a semistructured interview about their relationship with their partners, as explained to them. The interviews were recorded on audio and took place at the women's home, in a location offering privacy.

During the interview, the researcher had a script with the questions to be asked. Participants were informed about the procedure and its aims; and were also ensured of the confidentiality of their responses. After each interview, the researchers filled out a form called "field notes," aiming to record detailed information on the context in which the interview took place, non-verbal data and other relevant information, in accordance with the quality criteria for qualitative research of the Consolidated Criteria for Reporting Qualitative Research (COREQ) (Tong, Sainsbury, \& Craig, 2007).

The data collection team was composed exclusively of female students who, in pairs, approached the study participants. When administering the questionnaire, standardized instruments and conducting the interviews, one researcher remained with the participant while the other waited in another location at the woman's home. Usually, this second researcher talked to the interviewee's children or family members so that data collection could take place with greater privacy and without interruptions.

Data analysis. All 57 interviews were transcribed in full and analyzed using the technique of categorical and thematic content analysis proposed by Bardin (2011). Each interview received a numeric identification code to guarantee confidentiality during analysis. The transcripts were read and divided according to the interviewees' reports into groups of 
victims; perpetrators; those involved in mutual violence; and those who did not recognize participation in episodes of physical violence. This material was then read repeatedly to identify the pre-established analytical categories "context/ triggers of aggressions" and "controlling behavior," according to the previously established objectives.

The information reported by the participants was organized through successive framing approaches, aggregations and enumerations of the identified themes. Data categorization involved a triangulation process, in which two experienced researchers of violence verified the analysis and grouping procedures, before conducting the process of drawing inferences from the data.

\section{Ethical Considerations}

This study was approved by the Research Ethics Committee of the Universidade Federal de Juiz de Fora (CAAE No. 17920413.0.0000.5147). All participants signed the Free and Informed Consent Form before data collection.

Considering the private nature of the theme addressed, the researcher team that contacted the study's participants received specific training on how to approach and interview women involved in situations of violence. The training addressed the World Health Organization's recommendations about researching violence against women (Ellsberg \& Heise, 2005). The interviews were conducted in a location offering privacy to the participants. After the data collection procedure, all participants received an updated leaflet containing information about the health and psychosocial assistance services operating in the region.

\section{Results}

The average age of the 57 study participants was 45.2 years. Twenty-nine declared themselves white and 17 declared themselves black. They were predominantly Catholic (28) and evangelical/protestant (20). They had an average schooling of 9.5 years. Most worked (32) and were formally married (41). The average duration of the interviewees' relationships was 23 years. About $68 \%$ of them had up to 2 children.

Regarding alcohol use, 11 women had a score indicating risk of hazardous or harmful alcohol use in the initial survey (AUDIT $\geq 8$ ), of which 4 were interviewed in the second data collection. Partners' alcohol use was assessed using information provided by the women. Thus, as reported by the participants, among the 29 cases in which the partners had some level of problematic alcohol use in the first collection, 16 could be interviewed in the second survey.

Most of the second survey's interviews did not confirm the same CTS2 score obtained from the first collection, since many women stated that they had not been involved in intimate partner physical violence. Among the 57 women interviewed who reported intimate partner physical violence in the CTS2 in the first collection, only 27 reported the occurrence of these episodes in the second survey, with the remaining 30 interviewees not recognizing involvement in physical violence with their partners. In addition to these 27 women, another four reported violence in previous relationships, thus the qualitative analyzes presented below included 31 interviews.

With regard to the inconsistencies between the information collected by the quantitative and qualitative instruments, it is important to clarify that, considering the 57 interviews conducted, only four of the 15 interviewees of the group of victims reported episodes in which they were victims of physical violence by partners; of the 14 perpetrators of violence interviewed, only two reported aggression against their partners; of the 28 involved in mutual physical violence, only ten reported events of this nature in the interview.

Among the 30 women who did not report physical violence in the second survey's interview, 15 recognized the occurrence of psychological violence in their affective relationships. Although this type of violence was not the focus of our investigation, 11 interviewees spontaneously declared that psychological violence can be as or more harmful than physical violence.

The great majority of respondents stated that at the time of the interviews they were not experiencing physical violence in their relationships. Either they mentioned isolated episodes, or that these episodes happened in the past but have stopped. Only four of the interviewed women reported that episodes of intimate partner physical violence were currently happening (two as victims and two involved in mutual violence).

\section{Context/triggers of physical violence between partners}

Within the analysis category aimed at describing the context of intimate partner violence, we identified three subcategories that were more prevalent: personal characteristics of the perpetrator of the violence $(n=17)$; male partner's alcohol use $(n=15)$; aspects related to the affective and marital relationship $(\mathrm{n}=12)$. The predominance of these triggers was observed in the same proportion in the reports included in all three groups (victims, perpetrators and mutual violence). Some of the women reported more than one perceived reason for the assaults.

According to the participants, the perpetrators' personal characteristics would be relevant to the understanding of these events, thus locating the aggressiveness in the individual. In this sense, both the individuals' "way of being" - for example, "nervous," "rebellious," "hot temper" $(n=10)-$ and aspects of their mental health - such as psychiatric problems or difficulty childhoods $(n=7)-$ were mentioned as factors that might somehow explain the violence perpetrated, as exemplified by the following interview excerpts: "Because I am more nervous, so I let my anger rise" (perpetrator of the aggression, 14409); "He is a person who ... went had a very difficult childhood ... his mother was very violent ... he says that she used to threw him on the wall" (victim, 16604). 
For the interviewees, their partners' alcohol use influenced these episodes in different ways: by making the partner physically aggressive with them $(n=10)$; or by causing the partner to attack them verbally, which leads them to react physically $(n=3)$; or even when the consumption itself is viewed as a reason for female physical aggression $(n=2)$. In all these cases, alcohol seems to represent a factor external to the individual, capable of leading to aggression. Some of these situations are exemplified by the following excerpts: "He came home already drunk, then I began to complain ... he came to beat me ... I think it is the drink that makes one violent" (victim, 17707); "He was swearing at me ... Then I advanced [on him], it is my defense. ... I think it's really the drink. ... Because the person drinks, [then] arrives, [and] keeps saying things [he] shouldn't" (mutual violence, 16614).

Aspects related to the couple's affective and marital relationship, such as jealousy $(n=9)$ and disagreements in relation to sex $(n=3)$, were also mentioned as a contextual factor in physical aggressions, indicating that interpersonal conflicts lead to violence: "I was jealous of him with some girl ... and then ... I took the bamboo to beat him" (perpetrator of the aggression, 14409); "I don't agree with sex things with him like that. He thinks I'm a failure, so we fight and he offends me a lot. He even gets to push me out of the bed" (victim, 25005).

\section{Controlling Behavior}

Altogether, 10 reports indicated the occurrence of controlling behavior in the relationship among the 31 interviews that described episodes of physical violence. We sought to observe in these interviews whether the perpetrator of physical violence was also the person who attempted to control the partner's behavior, assessing if there was a combination of these types of violence, as described by Johnson (2011). Only one report described mutual controlling behavior in the dyad. In this case, the woman acknowledged having physically assaulted her partner, but pointed out that the aggressions were isolated events of little impact, according to her perception:

Only about twice. ... I threw a toy at him. ... It was nothing [serious]. He doesn't like that I have so much contact with people like that. ... Mainly ... my family is not from here, so I don't go there very often, [it is] very difficult. ... There are times when I feel sad about this. ... He controls me, [and] I control him, too. ... When he's like this at [other] people's homes, I say: "go out [there] a little." [I feel] angry. (perpetrator of the aggression, 14406)

Most reports of controlling behavior $(n=9)$ indicated that it was the male partner that attempted to control the female partner, and in six of these cases, the woman also suffered physical violence, a combination suggesting a more severe relationship of domination, such as exemplified by the following excerpt:

He [would] arrive [at home] already like this, he [would] arrive already assaulting [me] ... without any reason. ... He hit me, punched me ... slapped me in the face. ... I [would] do nothing, I was afraid of him. ... [I would] take the children and keep [them] on my arms so he wouldn't attack me anymore. ... When my mother and my uncle came to see me, he [would] put the gun on top of the television, [I] couldn't even talk. ... Ah, I felt very sad ... because I couldn't go to [one of my] aunts' house. ... It was very sad (victim, 18802).

We also identified cases $(n=2)$ in which violence was perpetrated by women in response to the partner's controlling behavior, suggesting that this behavior reached an extreme, unbearable level, hence the aggressive female reaction, as exemplified by the following excerpt:

I usually couldn't talk to other [people]. ... Especially men. ... He [would] drink, use drugs, get nervous and begin to swear. ... It irritated me, I was always irritated, that's why I got depressed. ... It was a day when I took something to beat him on the head, I was already feeling very much cornered by him ... [he kept] assaulting me, then I took the thing ... so I could kill him. ... I stopped, because ... I could [have] hurt him, because he was always drunk and I wasn't (perpetrator of the aggression, 18806).

There was also a case in which the physical violence was mutual, but in an isolated episode, with controlling behavior exerted by the male partner: "It was a fight, and I started to throw things at him and he threw [something at] me and [it] ended up hurting me. ... It happened just this time. ... [He] controls [my behavior] by phoning [me], yes. ... [He wants] to know where I am. ... [I feel] suffocated" (mutual violence, 26618).

It should be noted that most of the reports involving controlling behavior $(n=6)$ referred to interviewees' previous relationships, which had already ended by the time of data collection.

\section{Discussion}

It is important to highlight that our findings show differences in the data obtained from different instruments for measuring violence, which might contribute to the design of further studies. Data on the context of the aggressions perpetrated, as well as the presence of controlling behavior between partners, revealed varying degrees of domination in relationships, which are relevant aspects to understand the phenomenon. 


\section{Differences in measures of intimate partner violence}

A significant proportion of the reports obtained from the qualitative interviews did not agree with the interviewees' responses to the CTS2 questionnaire. More than half of the women who reported their involvement in episodes of intimate partner physical violence in the standardized instrument did not recognize, in the interview, the occurrence of such behavior in their affective relationships. Other studies have also found this type of inconsistency in the responses obtained from different instruments (Heyman, Feldbau-Kohn, Ehrensaft, Langhinrichsen-Rohling, \& O'Leary, 2001; Woodin et al., 2013). This incongruence between answers may have at least two explanations: some behaviors are not being perceived as violent (Barros \& Schraiber, 2017) and the difficulty inherent in talking about the topic (Morgan et al., 2016; Vieira \& Hasse, 2017).

Another possibility is that the episodes of violence have not been confirmed due to the time elapsed between the two surveys. This may suggest that such events happen at specific periods during the couple's life together, in "waves," with cycles and dynamics of violence varying over time (Katerndahl, Burge, Ferrer, Becho, \& Wood, 2012). Yet another possibility is that aggressions might happen in the course of life, but not as established relationship patterns (Testa, Hoffman, \& Leonard, 2011).

\section{Contexts/triggers of intimate partner physical violence}

As for the contexts of the episodes of violence, most reports point to the perpetrator's personal characteristics, to the male partner's alcohol use and to aspects related to the affective and conjugal relationship of those involved, regardless of who the perpetrator is and of whether the aggression was mutual or not. Some interviewees highlighted more than one trigger of violence. Such findings agree with the results of other studies (Bair-Merritt et al., 2015; Flynn \& Graham, 2010; Silva, Coelho, \& Njaine, 2014).

Specifically with respect to the role played by male alcohol use in the episodes of violence, most reports in our research indicated that the interviewees believed that their partners' consumption of alcohol made them aggressive. In this regard, it is important to examine the possibility that expectancies related to outcomes of alcohol use play a role in intimate partner violence, in addition to the effects of the use itself (Brasfield et al., 2016). Research suggests that the relationship between the use of alcoholic beverages and violent behavior is complex and non-linear (Brasfield et al., 2016; Capaldi et al., 2011; Gebara et al., 2015), being influenced, among other factors, by the amount of alcohol ingested.

\section{Controlling behavior}

In our study, controlling behavior by male partners was the most often mentioned by the interviewees, who also reported being physically assaulted by their controlling partners. Such situations might also involve more serious episodes of conjugal violence, given the existing relationship of domination (Johnson, 2011; Myhill \& Hohl, 2016). These cases would thus be difficult to be revealed by the victims in surveys conducted at their homes, given the difficulty of talking about a situation of oppression while still being in the relationship, making it more likely to obtain these reports regarding previous relationships (Johnson et al., 2014), a fact also observed in our data. However, it is important to notice that intimate partner violence is a complex and heterogeneous phenomenon and that there may be variations in gender rates of victimization and perpetration between different samples. In this sense, research data has shown that in a sample of university students controlling behavior is practiced about equally by men and women (Esquivel-Santoveña, Hernández, Viveros, Orozco, \& van Barneveld, 2020).

Some interviewees who declared having their behavior controlled by their partners mentioned that it caused feelings of sadness, irritation and anger. In this sense, Del Rio and Del Valle (2017) indicated that the presence of controlling behavior in combination with other types of intimate partner violence increases the likelihood of negative impacts on the victims' health at the time of these experiences. Lövestad, Löve, Vaez and Krantz (2017) identified that even when not combined with other forms of violence, controlling behavior is a risk factor for depression in women.

However, it is worth noting that our findings about controlling behavior in the analyzed sample seem to refer to qualitatively different situations, indicating the varying impacts that controlling behavior might have on relationships. The associated feelings, however, suggest that this conduct is negatively perceived by the victims, one of the criteria for characterizing coercive control in situations of intimate partner violence, according to Hamberger et al. (2017). In addition, controlling behaviors can sometimes be perceived as acceptable in a relationship, when associated with romantic beliefs (Papp, Liss, Erchull, Godfrey, \& Waaland-Kreutzer, 2017).

The possibility of extreme reactions of controlling behavior victims, with the use of physical violence, was exemplified in one of the reports obtained, similarly to situations described by Johnson (2011). However, in this case, the male partner's controlling behavior did not involve physical violence perpetrated by him, which possibly would not allow categorizing this case as "violent resistance." Emery (2011) describes cases in which subordinate partners would use fewer offensive forms of physical violence for displaying dissatisfaction with the established power structure.

In our study, some women spontaneously reported that psychological aggression can be equally or more harmful than physical violence. Considering that high levels of psychological aggression can be used to operationalize coercive control (Straus \& Gozjolko, 2014), we may assume that these reports could also refer to situations involving controlling behavior. In this sense, it should be noted that there is no consensual measure of controlling behavior, and it is also difficult to determine to what extent certain behaviors 
are abusive (Hamberger et al., 2017; Johnson et al., 2014; Straus \& Gozjolko, 2014). In view of these difficulties of studying controlling behavior, Emery (2011) suggests assessing the degree of control/power exerted by the partners in a relationship. This would help to understand intimate partner violence and its theoretical development.

As limitations of our research, we mention the reduced number of reports of violence obtained, since a significant part of the participants who reported violence in the standardized instrument did not confirm this information in the interview. In this sense, the difficulty in addressing the subject due to its private nature, the memory bias and the unilateral reporting of the episodes of violence are also limitations observed in our study. In addition, the time elapsed between the two surveys may have contributed to the non-confirmation of violence in the interviews. Thus, follow-up of samples with more assessments at smaller intervals might allow greater precision in the characterization of how these dynamics of violence vary over time. Nevertheless, the sample's origin, namely, from a probabilistic community household survey, with longitudinal data collection, give relevance to the study.

Our study evidenced the need for caution in using data obtained from a single measurement instrument and from a restricted operationalization of the phenomenon investigated. It also revealed triggers of intimate partner physical violence in the sample, suggesting that they are common among the groups of perpetrators, victims and of those involved in mutual violence.

Controlling behaviors among the interviewees were mostly portrayed as a male behavior that occurred in previous relationships and which also involved physical violence. This was a relevant aspect of the reports obtained, with varying degrees of impact on the relationships. We thus suggest that this issue should be further studied in order to better understand the dynamics of intimate partner violence by assessing the degree of power and control exerted.

\section{References}

Babor, T. F., Higgins-Biddle, J. C., Saunders, J. B., \& Monteiro, M. G. (2006). AUDIT: Teste para identificação de problemas relacionados ao uso de álcool: Roteiro para uso em atenção primária [AUDIT: Test to identify problems related to alcohol use: A guide for use in primary care] (C. M. Corradi, Trans.). Ribeirão Preto, SP: PAI-PAD/FMRP-USP.

Bardin, L. (2011). Análise de conteúdo [Content analysis] (L. A. Reto \& A. Pinheiro, Trans.). Lisboa, Portugal: Edições 70 .

Bair-Merritt, M. H., Mandal, M., Epstein, N. B., Werlinich, C. A., \& Kerrigan, D. (2015). The context of violent disagreements between parents: A qualitative analysis from parent's reports. BMC Public Health, 14, 1324. doi:10.1186/1471-2458-14-1324
Barros, C. R. S., \& Schraiber, L. B. (2017). Intimate partner violence reported by female and male users of healthcare units. Revista de Saúde Pública, 51, 7. doi:10.1590/ s1518-8787.2017051006385

Brasfield, H., Morean, M. E., Febres, J., Shorey, R. C., Moore, T. M., Zapor, H. Z., ... Stuart, G. L. (2016). Alcohol use, alcohol-related outcome expectancies, and partner aggression among males court-mandated to batterer intervention programs: A brief report. Journal of Interpersonal Violence, 31(2), 245-256. doi: $10.1177 / 0886260514555366$

Capaldi, D. M., Knoble, N. B., Shortt, J. W., \& Kim, H. K. (2012). A systematic review of risk factors for intimate partner violence. Partner Abuse, 3(2), 231-280. doi:10.1891/1946-6560.3.2.231

Dahlberg, L. L., \& Krug, E. G. (2006). Violência: Um problema global de saúde pública [Violence: A global public health problem]. Ciência \& Saúde Coletiva, 11(Supl.), 11631178. doi:10.1590/S1413-81232006000500007

Del Rio, I. D., \& Del Valle, E. S. G. (2017). The consequences of intimate partner violence on health: A further disaggregation of psychological violence - evidence from Spain. Violence Against Women, 23(14), 1771-1789. doi: $10.1177 / 1077801216671220$

Ellsberg, M., \& Heise, L. (2005). Researching violence against women: A practical guide for researchers and activists. Washington, DC, United States: World Health Organization/PATH. Retrieved from http://apps.who.int/ iris/bitstream/10665/42966/1/9241546476_eng.pdf

Emery, C. R. (2011). Disorder or deviant order? Retheorizing domestic violence in terms of order, power and legitimacy: A typology. Aggression and Violent Behavior, 16(6), 525-540. doi:10.1016/j.avb.2011.07.001

Esquivel-Santoveña, E. E., Hernández, R. R., Viveros, N. C., Orozco, F. L., \& van Barneveld, H. O. (2020). Physical intimate partner violence and controlling behavior in Mexican university students and their attitudes toward social limits. Journal of Interpersonal Violence, 35(1-2), 403-425. doi:10.1177/0886260516681879

Flynn, A., \& Graham, K. (2010). "Why did it happen?" A review and conceptual framework for research on perpetrators' and victims' explanations for intimate partner violence. Aggression and Violent Behavior, 15(3), 239-251. doi:10.1016/j.avb.2010.01.002

Garcia-Moreno, C., Jansen, H. A. F. M., Ellsberg, M., Heise, L., \& Watts, C. H. (2006). Prevalence of intimate partner violence: Findings from the WHO multi-country study on women's health and domestic violence. Lancet, 368(9543), 1260-1269. doi:10.1016/S01406736(06)69523-8 
Gebara, C. F. P., Ferri, C. P., Lourenço, L. M., Vieira, M. T., Bhona, F. M. C., \& Noto, A. R. (2015). Patterns of domestic violence and alcohol consumption among women and the effectiveness of a brief intervention in a household setting: A protocol study. BMC Womens Health, 15, 78. doi:10.1186/s12905-015-0236-8

Hamberger, L. K., Larsen, S. E., \& Lehrner, A. (2017). Coercitive control in intimate partner violence. Aggression and Violent Behavior, 37, 1-11. doi:10.1016/j. avb.2017.08.003

Heyman, R. E., Feldbau-Kohn, S. R., Ehrensaft, M. K., Langhinrichsen-Rohling, J., \& O'Leary, K. D. (2001). Can questionnaire reports correctly classify relationship distress and partner physical abuse? Journal of Family Psychology, 15(2), 334-346. doi:10.1037//08933200.15.2.334

Johnson, M. P. (2011). Gender and types of intimate partner violence: A response to an anti-feminist literature review. Aggression and Violent Behavior, 16(4), 289-296. doi:10.1016/j.avb.2011.04.006

Johnson, M. P., Leone, J. M., \& Xu, Y. (2014). Intimate terrorism and situational couple violence in general surveys: Ex-spouses required. Violence Against Women, 20(2), 186-207. doi:10.1177/1077801214521324

Katerndahl, D. A., Burge, S. K., Ferrer, R. L., Becho, J., \& Wood, R. C. (2012). Understanding intimate partner violence dynamics using mixed methods. Families, Systems \& Health, 30(2), 141-153. doi:10.1037/a0028603

Lima, C. T., Freire, A. C., Silva, A. P., Teixeira, R. M., Farrell, M., \& Prince, M. (2005). Concurrent and construct validity of the audit in an urban Brazilian sample. Alcohol and Alcoholism, 40(6), 584-589. doi:10.1093/ alcalc/agh202

Lövestad, S., Löve, J., Vaez, M., \& Krantz, G. (2017). Prevalence of intimate partner violence and its association with symptoms of depression; a cross-sectional study based on a female population sample in Sweden. $B M C$ Public Health, 17(1), 335. doi:10.1186/s12889-0174222-y

Moraes, C. L., Hasselmann, M. H., \& Reichenheim, M. E. (2002). Adaptação transcultural do instrumento "Revised Conflict Tactic Scales (CTS2)", utilizado para identificar violência entre casais [Transcultural adaptation of the "Revised Conflict Tactic Scales (CTS2)", instrument used to identify violence between couples]. Cadernos de Saúde Pública, 18(1), 163-176. doi:10.1590/S0102311X2002000100017

Morgan, K., Buller, A. M., Evans, M., Trevillion, K., Williamson, E., \& Malpass, A. (2016). The role of gender, sexuality, context upon help seeking for intimate partner violence: A synthesis of data across five studies. Aggression and Violent Behavior, 31, 136-146. doi:10.1016/j.avb.2016.09.001
Myhill, A., \& Hohl, K. (2016). The "Golden Thread": Coercitive control and risk assessment for domestic violence. Journal of Interpersonal Violence, 34(21-22), 4477-4497. doi:10.1177/0886260516675464

Papp, L. J., Liss, M., Erchull, M. J., Godfrey, H., \& WaalandKreutzer, L. (2017). The dark side of heterosexual romance: Endorsement of romantic beliefs relates to intimate partner violence. Sex Roles: A Journal of Research, 76(1-2), 99-109. doi:10.1007/s11199-0160668-0

Razera, J., Mosmann, C. P., \& Falcke, D. (2016). The interface between quality and violence in marital relationships. Paidéia (Ribeirão Preto), 26(63), 71-79. doi:10.1590/1982-43272663201609

Reichenheim, M. E., Klein, R., \& Moraes, C. L. (2007). Assessing the physical violence component of the Revised Conflict Tactics Scales when used in heterosexual couples: An item response theory analysis. Cadernos de Saúde Pública, 23(1), 53-62. doi:10.1590/S0102311X2007000100007

Silva, A. C. L. G., Coelho, E. B. S., \& Njaine, K. (2014). Violência conjugal: As controvérsias nos relatos dos parceiros íntimos em inquéritos policiais [Marital violence: The controversies in the reports of the intimate partners in police investigation]. Ciência \& Saúde Coletiva, 19(4), 1255-1262. doi:10.1590/141381232014194.01202013

Straus, M. A., \& Gozjolko, K. L. (2014). "Intimate terrorism" and gender differences in injury of dating partners by male and female university students. Journal of Family Violence, 29(1), 51-65. doi:10.1007/s10896-013-9560-7

Testa, M., Hoffman, J. H., \& Leonard, K. E. (2011). Female intimate partner violence perpetration: Stability and predictors of mutual and non mutual aggression across the first year of college. Aggressive Behavior, 37(4), 362373. doi:10.1002/ab.20391

Tong, A., Sainsbury, P., \& Craig, J. (2007). Consolidated criteria for reporting qualitative research (COREQ): A 32-item checklist for interviews and focus groups. International Journal for Quality in Health Care, 19(6), 349-357. doi:10.1093/intqhe/mzm042

Vieira, E. M., \& Hasse, M. (2017). Percepções dos profissionais de uma rede intersetorial sobre o atendimento a mulheres em situação de violência [Perceptions of professionals in anintersectorial network about the assistance of women in situation of violence]. Interface - Comunicação, Saúde, Educação, 21(60), 5162. doi:10.1590/1807-57622015.0357

Woodin, E. M., Sotskova, A., \& O'Leary, K. D. (2013). Intimate partner violence assessment in an historical context: Divergent approaches and opportunities for progress. Sex Roles: A Journal of Research, 69(3-4), 120130. doi:10.1007/s11199-013-0294-z 
Fernanda Monteiro de Castro Bhona is a Forensic Psychologist at Tribunal de Justiça de Minas Gerais, Juiz de Fora-MG, Brazil.

Carla Ferreira de Paula Gebara is a Professor of the Psychology Department at Universidade Católica de Petropólis, Petropólis-RJ, Brazil.

Ana Regina Noto is a Professor of the Psychobiology Department at Universidade Federal de São Paulo, São Paulo-SP, Brazil.

Lélio Moura Lourenço is a Professor of the Psychology Department at Universidade Federal de Juiz de Fora, Juiz de Fora-MG, Brazil.

Authors' Contribution:

All authors made substantial contributions to the conception and design of this study, to data analysis and interpretation, and to the manuscript revision and approval of the final version. All the authors assume public responsibility for content of the manuscript.

Received: Jan. 20, 2019

1st Revision: Jul. 06, 2019

2nd Revision: Dec. 09, 2019

Approved: Dec. 11, 2019

How to cite this article:

Bhona, F.M.C., Gebara, C.F.P., Noto,A.R., \& Lourenço,L.M.

(2020). Intimate partner violence: Controlling behavior and triggers of aggression. Paidéia (Ribeirão Preto), 30, e3032.doi:https://doi.org/10.1590/1982-4327e3032 